\title{
Welcome Address for First Science Mathematicg
}

\author{
Anthony G. O'Farrell
}

'It's better to be rich and happy than poor and sad.'
- a Linux login message

1. 'Is fearr a bheith saibhir agus sona ná bocht agus brónach."

Fáilte, a chairde nua, go Má Nuad, agus go háirithe go cúram ceansa Roinn na Matamaitice. Thar mo cheann féin, agus thar cheann mhuintir na Roinne, tugaim fájlte $\delta$ chroí romhaibh uile ... (\& rl., ad libitum, dum quiescant).

2. 'It's better to be rich and happy than poor and sad.' I picked this little proposition because I can easily prove it, and to remark that like its proof, all mathematics is essentially simple. The power of mathematics rests not on its complexity, but on its ability to make complexity manageable. Some say that it is better to be poor and happy than rich and sad. It may be so, but opinions differ. I assume that, other things being equal, it is better to be rich than poor, and that, other things being equal, it is better to be happy than sad. I then argue that rich and happy is better than rich and sad, that rich and sad is better than poor and sad, and hence rich and happy is better than poor and sad.

All mathematical argument reduces to simple steps of this kind. Mathematics is a reasonable activity. If you don't understand something that we tell you, you may insisf on an explanation, and we can break it down, and down, and down to elementary, intelligible steps. Everyone can understand Mathematics, given time.

3. Here's a wonderful thing: I've spent almost my entire professional life in universities, and, more than anything else, I've tried to figure out what goes on in the geometry of imaginary worlds, spaces of $4,6,8$ dimensions, even infinite dimensions, and yet they pay me literally millions, I get invited all over the world to talk about it, I get to work in this beautiful place, and, best of all, every September a thousand new youngsters flock in the door, full of hope and enthusiasm, to brighten my days and gladden my heart.

4. I do understand that not all freshmen are equally ready.

As Proverbs has it:

1 looked through my casement

And beheld among the simple ones,

I discerned among the youths, a young man void of understanding.

But 1 rejoice in that too: the essential vocation of a professor includes the struggle to dispel ignorance and confusion, to share knowledge and understanding. The beauty of it is that knowledge and understanding may be shared without diminishing, on the contrary: 
There is that scattereth, and yet increaseth ...

The liberal soul shall be made fat: and he that watereth shall be watered also himself.

5. I started school at the Sacred Heart Convent in Roscrea in August, 1951. Every Autumn since, I've gone back to school. 1 always learn something, but for you it is, of course, special this year: you are starting at the University.

The Department of Education organises elementary and secondary education into 'cycles'. They talk of 'Junior Cycle' and 'Senior Cycle'. But a cycle is a wheel, and these are not cycles. You do them once, and you do not arrive where you began. In the trajectory of your life you live each day once, and in your education you grow in wisdom, age, and grace. What part does the University play in this development?

The best metaphor is in Genesis. Bereshit berah Elohim ... ; in the beginning God created the heaven and the earth, formless and void. After a while, He made light, and everything changed. Starting at the University is your first exposure to the light.

\section{What is a University?}

Fundamentally, it is a truth-place. Truth is at the centre. What is truth? Truth is how things are. It is the only possible basis for reasonable action: you have to know how things are before you can make a reasonable decision about anything. But even apart from relevance to action, people need truth: we are hard-wired to crave it. The University exists to find truth, to teach it, and to train people to find it for themselves.

This ideal is implemented in practice by a community of scholars that, by law, is free 'to pursue and propagate ideas, without restriction on the range of enquiry or the publication of results".

7. You and I belong to this community of scholars. Our fellows are the senior undergraduate and postgraduate students, the post-doctoral researchers, lecturers and professors, and the academic officers such as Deans, Registrar and President. There is a certain hierarchy here, but it does not override the demands of truth.

A couple of stories will illustrate the point.

8. When the mathematician Hahn was young he went to school in Potsdam, where the Kaiser had a palace. The emperor's children were sent to the public Gymnasium, because the Kaiser could conceive of no better education for anyone, even a prince. One of the princes was in class with Hahn, who told this story: 
The prince was not good at mathematics. One day the teacher was explaining a theorem. The prince did not get the proof. The teacher explained several times. Still, the prince did not understand, and finally he exclaimed: 'It's just impossible! This proof cannot be correct!' The teacher said: 'Your Royal Highness, I give you my word of honour that it is correct.' The prince smiled and said: 'My dear fellow! Why didn't you say that in the first place!'

(Int. Math. Nachrichten 18 I (1999) p. 2)

You see, the prince trusted authority, and needed no proof once authority had spoken.

This is not how it should be between you and me. I am in authority over you, but my authority is only as good as the truth of what 1 tell you. You should feel free to challenge what the academics tell you. (Of course, your challenges should be polite.)

9. The second story (which I leamed of from T. W. Korner) concems the famous Karl Pearson, the 'father of modem statistics'. He once said that his earliest memory was of sitting in a high chair and sucking his thumb. His nurse told him to stop, or it would wither away. The infant Pearson put his two thumbs side by side, and studied them for a long time. He thought: "They look the same to me. The one I suck appears no smaller than the other. I wonder if she could be lying to me?' $H$. M. Walker remarked that in this simple anecdote we have (a) rejection of constituted authority, (b) appeal to empirical evidence, (c) faith in his own interpretation of the meaning of observed data and, finally, (d) imputation of moral obliquity to a person whose judgment differed from his own.

(T.W.Korner, Fourier Analysis, p. 419)

Apart from the latter, these qualities are high among those you should cultivate if you are to become an effective scientist.

10. What is Mathematics?

This is a philosophical question. Mathematics is silent on the subject. The root of the word is in the Greek $\mu \alpha \theta \varepsilon i v-t o$ learn. For instance $\mu \alpha v \theta a v e i s$ means 'get it??'. It may have got this name because, of all subjects, it is the one you have to be laught.

It has been defined as the science of space and quantity, i.e., the tool by which we order all things by measure, number and weight. This definition is, however, inadequate to encompass the range of things mathematicians do. It illustrates the peril that awaits any philosopher who would define mathematies without understanding it first.

Several mathematicians have offered definitions. For instance, Hermann Weyl said mathematics is 'the science of the infinive', and G. H. Hardy that 'a mathematician is a masser of pattern'. These are more to the point, but I agree 
with André Weil, who said: 'Asking a mathematician to define mathematics is like asking a dog to define a bone. He knows it when he sees it'.

11. Whatever it is, Mathematics exhibits the following characteristics: it is universal, true, abstract, simple, a voracious user of symbols, useful, and for some people it is fun.

12. Mathematics is universal: although made by people, it does not depend on their opinions, or even on the facts of the world. If apples fell upwards, Mathematics would not change. So it is even more than universal, in the sense that in other universes the facts of Mathematics would be the same.

13. Mathematics is true: isn't it?

14. Mathematics is abstract: the objects of mathematics are abstract ideas, concepts such as '2', 'point', 'fair coin', or 'plane cubic curve'. Abstract is the opposite of concrete, so most people would say that mathematical concepts are not real things. Then again, some people say that real things are just the ideas we have of them. If you stan to think about how real an idea might be, think about seahorses and unicoms. When I was young I thought that both seahorses and unicoms were mythical creatures. I knew rather more about unicoms, because they appeared in better stories. Then, one day, I visited an aquarium and saw a seahorse. What changed? I still know more about unicoms, even though they don't exist as real things.

15. Mathematics is simple: the fact that mathematical arguments may be reduced to simple steps is nicely illustrated by the story of the philosopher Thomas Hobbes (1588-1679), as told by Aubrey in his book Brief Lives:

He was 40 years old before he looked on Geometry; which happened accidentally. Being in a Gentleman's Library, Euclid's Elements lay open, and "twas the 47 EI. Libri I. He read the Proposition. By G--, said he (he would now and then swear an emphatical oath by way of emphasis), this is impossible! So he reads the Demonstration of it, which referred him back to such a Proposition; which proposition he read. That referred him back to another, which he also read. Et sic deinceps-that at last he was demonstratively convinced of that truth. This made him in love with Geometry.

16. Symbols abound: $+-\mathrm{x} \div / \approx \sqrt{ }^{3} \sqrt{ }=\left\langle>\iint \sum \infty \nabla \Delta \uparrow \# \Phi \otimes \oplus\right\rceil$ $\cap \cup \exists \forall-\therefore \because \subset \subseteq \propto \beta\lceil\equiv \theta$. They serve to encapsulate ideas and permit economy of expression.

17. Everyone knows how useful Mathematics is. It penetrates every aspect of our civilization, and etrables most of it. It empowers you, greatly magnifying your ability to do good, or evil.

However, power isn't everything, and most professional mathematicians are motivated by something else. 
18. The practice of mathematics gives a pleasure like no other occupation. The staff of the Mathematics Department are in thrall to it. For those whose temperaments and talents are suited to it, the subject guarantees an endless variety of challenges.

19. People may be unaware that new mathematics is being explored all the time. That is what the postgraduate researchers and the academics in the Mathematics Department do all day, when they are not teaching or filling out forms for the administration.

20. Mathematics is a broad church. It has room for left-brain folk (excelling at speech, symbolism and reason) and right-brain folk (strong on spatial abilities and music). It has room for serious, even humourless folk, and outright pranksters. Never underestimate fun.

21. Given your present level of mathematical education, I cannot explain to you what kind of problems our people work on. That will have to wait. If you would like to learn something about the most famous unsolved problems in mathematics at present, check out the Clay Institute Prizes. These prizes of $\$ 1 m$ were offered for solutions to problems like proving the Riemann Hypothesis.

22. One of the reasons mathematics is so useful is the occurrence of structural isomorphism between different things, and another is the existence of deep connections between different fields. Examples of connections are:

$$
\begin{aligned}
& \text { maze } \leftrightarrow \text { graph } \leftrightarrow \text { matrix } \\
& \text { stability of marriage } \leftrightarrow \text { CAO process } \\
& \text { complex numbers, poles } \leftrightarrow \text { stability of aircraft } \\
& \text { quaternions } \leftrightarrow \text { computer graphics } \leftrightarrow \text { Lara Croft } \\
& \text { golden ratio } \leftrightarrow \text { continued fraction }
\end{aligned}
$$

23. Often, a new application results from a kind of joke: a mental shift, a new way of looking at something. Examples are the invention of the slide rule or the digital computer.

24. Returning to wealth and happiness, what does it mean to be rich?

- To have a lot of money?

- To have all the money there is?

- To have enough?

- Or to want no more than you have?

25. What does it mean to be happy?

- To be ecstatic? If so, it happens as my friend Verdera says, only on a fractal set on the time axis.

- To be free from frustration and pain? No, for pain tells us we are alive. In a way, all that really matters is to feel, to care, to be passionate. 
- To have your heart's desire? Yes, but only if what you desire is fit for you. Be careful what you set your heart on, because you will probably get it.

Opinions differ. Mine is that happiness is harmony-being true to our nature in our lives and relationships.

26. The way to happiness is not to try. We have some say in what happens to us, but we are not in control. I like Marriqué's image:

Nuestras vidas son los rios, qui van a dar en el mar.

(Our lives are rivers, which go to surrender in the sea).

Life is best enjoyed like "tubing": just sit in and see where the river takes you.

To be true to yourself does not mean to think all the time about yourself. Often, it means the opposite: to forget yourself, to lose yourself in your preoccupation. In that state you don't mind the resistance, the hardship, the 'polvo, sudor, la sed y la fatiga' (Machado).

27. The university is not a community of contemplatives, but active and interactive.

It is quite legitimate for a person to seek perfection by imitating the desert fathers, dining sporadically on cabbage-leaves and contemplating the infinite, but we don't do that here.

We seek truth, and find some, some nuggets.

28. As to why, most of the possible motives are rehearsed in this quotation from St. Bernard of Clairvaux:

Sunt namque qui scire volunt, eo fine tantum, ut sciant; et turpis curiositas est. Et sunt gui scire volunt, ut sciantur ipsi, et turpis vanitas est.

Et sunt item qui scire volunt, ut scientiam suam vendant,

Verbi causa, pro pecunia, pro honoribus, et iurpis quaestus est.

Sed sunt quoque qui scire volunt, ut aedificent, et charitas est.

Et item qui scire volunt, ut aedificentur, et prudentia est.

(For there are some who wish to know things simply to know them-a shameful curiosity.

And there are those who wish to know things in order to be famous-a shameful vanity.

There are also people who wish to know things so that they can sell their knowledge for money or honours-a shameful ambition.

But there are also people who wish to know things in order to enlighten others, and this is charity.

There are also those who wish to know things in order that they may themselves be enlightened, and this is prudence.)

Missing from Bernard's list is the important motive of simple fun, and play. Newton, near the end of his life, said that it seemed to him that he had been 
like a child playing on the seashore, picking up pebbles and occasionally finding one prettier that the next, while before him lay the vast sea of unexplored truth. This could be read in a dark sense, referring to the futility of scientific inquiry, rather like St. Thomas Aquinas's last words ('All straw, all straw...'), but the image of the child at play is quite apt as a simile for the approach of many scholars to their subjects.

29. Finally, it is as well to understand the limits of the University.

\section{T.S. Eliot said:}

The endless cycle of idea and action,

Endless invention, endless experiment,

Gives knowledge of speech, but not of silence,

Knowledge of words, but ignorance of The Word.

He was more-or-less right. We all have a deep need for times of silence. But there are things beyond words and even beyond silence. These can only be hinted at in language. An example is Borges' story, 'The Yellow Rose', in which the dying philosopher gazes at the rose beside his bed, and suddenly turns his face to the wall. We cannot really penetrate to the essence of things, even though we may occasionally glimpse their beauty, their terror, and their wonder.

There are things about a yellow rose that defeat all the philosophers. And there are things about red-headed girls that defeat even mathematicians.

Agus fágfaimid siúd mar atá sé. 